\title{
Abstract \\ The Decoupling of Corrosion and Fatigue for Aircraft Service Life Management ${ }^{\dagger}$
}

\section{Loris Molent}

Citation: Molent, L. The Decoupling of Corrosion and Fatigue for Aircraft Service Life Management. Mater. Proc. 2021, 6, 23. https://doi.org/ 10.3390/CMDWC2021-09998

Academic Editor: Rhys Jones AC

Published: 8 May 2021

Publisher's Note: MDPI stays neutral with regard to jurisdictional claims in published maps and institutional affiliations.

Copyright: (C) 2021 by the author. Licensee MDPI, Basel, Switzerland. This article is an open access article distributed under the terms and conditions of the Creative Commons Attribution (CC BY) license (https:// creativecommons.org/licenses/by/ $4.0 /)$.
Aerostructures Consultant and Trainer, Melbourne 3056, Australia; clanmolent@bigpond.com; Tel.: +61-413474318 + Presented at the First Corrosion and Materials Degradation Web Conference, 17-19 May 2021; Available online: https://cmdwc2021.sciforum.net/.

\begin{abstract}
Metal fatigue management is generally well understood as reflected in the Aircraft Structural Integrity Management Plans, which, in some cases, consider environmental degradation prevention; however, limited provisions beyond find and fix exist for corrosion repair. Thus, the repair of corrosion can be a major undertaking, through life cost driver and an aircraft availability degrader. This find and fix approach exists largely because tools are too immature to accurately assess the structural significance of corrosion when it is detected. This presentation shows that fatigue and corrosion are decoupled for aircraft in general through the analysis of some in-service cracking cases. Corrosion occurs on the ground, whilst fatigue cycling occurs at altitude. This important observation allows fatigue and corrosion to be considered separately. This work aims to provide a crack growth basis for the justification of allowing detected pitting corrosion to remain in service for a limited period before repair.
\end{abstract}

Keywords: aircraft fatigue; corrosion pits; crack growth

Supplementary Materials: The conference presentation file is available at https:/ /www.mdpi.com/ article/10.3390/CMDWC2021-09998/s1.

Institutional Review Board Statement: Not applicable.

Informed Consent Statement: Not applicable.

Data Availability Statement: Not applicable.

Acknowledgments: The author is indebted to numerous colleagues over many years who helped formulate the position presented. 